\title{
SHARPIN wt Allele
}

National Cancer Institute

\section{Source}

National Cancer Institute. SHARPIN wt Allele. NCI Thesaurus. Code C101612.

Human SHARPIN wild-type allele is located in the vicinity of $8 \mathrm{q} 24.3$ and is approximately 9

$\mathrm{kb}$ in length. This allele, which encodes sharpin protein, plays a role in ubiquitin

polymerization. 